\title{
Thymus serpyllum Essential Oil and Its Biological Activity as a Modern Food Preserver
}

\author{
Lucia Galovičová ${ }^{1, * \mathbb{D}}$, Petra Borotová ${ }^{2,3}$, Veronika Valková ${ }^{1,3}$, Nenad L. Vukovic ${ }^{4}$, Milena Vukic ${ }^{4}$,

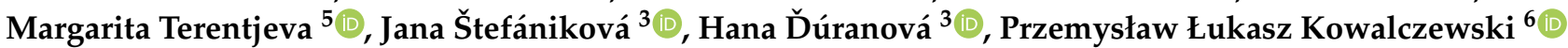 \\ and Miroslava Kačániová 1,7,*D
}

1 Department of Fruit Sciences, Viticulture and Enology, Faculty of Horticulture and Landscape Engineering, Slovak University of Agriculture, Tr. A. Hlinku 2, 94976 Nitra, Slovakia; veronika.valkova@uniag.sk

2 Department of Animal Physiology, Faculty of Biotechnology and Food Sciences, Slovak University of Agriculture, Tr. A. Hlinku 2, 94976 Nitra, Slovakia; petra.borotova@uniag.sk

3 AgroBioTech Research Centre, Slovak University of Agriculture, Tr. A. Hlinku 2, 94976 Nitra, Slovakia; jana.stefanikova@uniag.sk (J.Š.); hana.duranova@uniag.sk (H.Ď.)

4 Department of Chemistry, Faculty of Science, University of Kragujevac, 34000 Kragujevac, Serbia; nvchem@yahoo.com (N.L.V.); milena.vukic@pmf.kg.ac.rs (M.V.)

5 Faculty of Veterinary Medicine, Institute of Food and Environmental Hygiene, Latvia University of Life Sciences and Technologies, K. Helmana iela 8, LV-3004 Jelgava, Latvia; margarita.terentjeva@llu.lv

6 Department of Food Technology of Plant Origin, Poznań University of Life Sciences, 31 Wojska Polskiego St., 60624 Poznań, Poland; przemyslaw.kowalczewski@up.poznan.pl

7 Department of Bioenergy, Food Technology and Microbiology, Institute of Food Technology and Nutrition, University of Rzeszow, Zelwerowicza St. 4, 35601 Rzeszow, Poland

check for updates

Citation: Galovičová, L.; Borotová, P.; Valková, V.; Vukovic, N.L.; Vukic, M.; Terentjeva, M.; Štefániková, J.; Dúranová, H.; Kowalczewski, P.Ł.; Kačániová, M. Thymus serpyllum Essential Oil and Its Biological Activity as a Modern Food Preserver. Plants 2021, 10, 1416. https:// doi.org/10.3390/plants10071416

Academic Editor: Stefania Garzoli

Received: 17 June 2021

Accepted: 8 July 2021

Published: 11 July 2021

Publisher's Note: MDPI stays neutral with regard to jurisdictional claims in published maps and institutional affiliations.

Copyright: (c) 2021 by the authors. Licensee MDPI, Basel, Switzerland. This article is an open access article distributed under the terms and conditions of the Creative Commons Attribution (CC BY) license (https:// creativecommons.org/licenses/by/ $4.0 /)$.
* Correspondence: l.galovicova95@gmail.com (L.G.); miroslava.kacaniova@gmail.com (M.K.)

Abstract: The aim of this study was to analyze the chemical composition and biological and antibiofilm activity of the essential oil (EO) of Thymus serpyllum with the use of a MALDI-TOF MS Biotyper. The main compounds of the EO were thymol, $18.8 \%$; carvacrol, $17.4 \%$; o-cymene, $15.4 \%$; and geraniol, $10.7 \%$. It was found that free-radical scavenging activity was high. The highest antimicrobial activity was observed against Pseudomonas aeruginosa, Salmonella enteritidis, and biofilm-forming bacteria. The changes in the biofilm structure after T. serpyllum EO application confirmed the inhibitory action and the most pronounced effect was observed on Bacillus subtilis biofilm. The antifungal activity of the vapor phase was the most effective against Penicillium crustosum. T. serpyllum should be a suitable alternative to synthetic antioxidants as well as antimicrobials. The EO of T. serpyllum can be used in the vapor phase in the storage of root vegetables as well as a growth inhibitor of Penicillium on bread.

Keywords: Thymus serpyllum; biofilm; MALDI-TOF MS Biotyper; Penicillium; bacillus; stenotrophomonas

\section{Introduction}

Thymus serpyllum or wild thyme of the family Lamiaceae is an aromatic flowering plant which contains high amounts of essential oils (EOs) rich in polyphenolic compoundsphenolic acids or flavonoids. EOs are biologically active substances with polyphenolic compounds which exhibit high radical scavenging potential and anti-inflammatory activity [1]. These properties are used in the pharmaceutical industry for pharmaceutical preparations such as antihypertensive, anti-inflammatory, antiproliferative, and anticancer medicines. The origin of T. serpyllum is Mediterranean Europe and Africa, and it is typical that the plant vegetation is observed at higher altitudes [2]. T. serpyllum extracts possess antibacterial, antimicrobial, antifungal, and insecticidal effects [3]. EOs are known to exhibit this effect on the growth and development of the microorganisms and this is especially important in the prevention of contamination with spoilage and pathogenic microorganisms. T. serpyllum EO exhibits a strong inhibitory effect on the growth of Gram-positive 
and Gram-negative bacteria, and against yeasts [4,5]. T. serpyllum EO also has an inhibitory effect against biofilm-forming microorganisms. Inhibition of the biofilm growth has been observed with Salmonella Enteritidis [6] and Enterococcus faecalis [7].

Biofilm is a bacterial community which forms a structured consortium. Gram-positive, Gram-negative bacteria, and also yeasts strains are able to form biofilm. The biofilm can be attached to surfaces of different structures and functions and it is surrounded by an extracellular polymer matrix produced by the cell. The biofilm occurs in two stages-the planktonic stage and the adherent stage. The formed biofilm is adapted to adverse environmental conditions such as the presence of antimicrobials [8]. The bacteria of the adherent biofilm are more resistant to the antimicrobials used in their elimination than the bacteria of the planktonic stage [9]. The demand for natural alternatives to chemical preservatives, antioxidants, and antimicrobials to ensure food safety and minimize public health hazards is still growing. The negative effects of increased use of synthetic antioxidants on consumer health have been reported [10]. There is an interest in exploring natural alternatives since it is known that the application of chemical agents can result in liver damage as well as an increased incidence of cancers [10].

Microscopic techniques are often used to study morphological and structural changes in bacterial biofilms. The matrix-assisted laser desorption ionization time-of-flight mass spectrometry (MALDI-TOF MS) is used for characterization of different bacterial biofilms and is recognized as a suitable alternative to microscopic techniques [11].

The aims of the present study were to analyze the chemical composition and, antioxidant, antimicrobial, and antibiofilm activity of essential oil of Thymus serpyllum from the Slovak region. Evaluation of the inhibitory activity of EO on biofilms by MALDI-TOF MS is a relatively novel technique and our aim was to detect the structural and molecular changes in Stenotrophomonas maltophilia and Bacillus subtilis biofilm with constructed dendrograms constructed from mass spectra. The ability to detect the effectiveness in the gas phase, in a food model, against biofilm-forming bacteria and Penicillium spp. was also tested.

\section{Results}

\subsection{Chemical Composition of Thymus serpyllum Essential Oil}

Gas chromatography/mass spectrometry (GC/MS) and gas chromatography (GCFID) of T. serpyllum EO was used for detection and the major compounds were found to be thymol, $18.8 \%$; carvacrol, $17.4 \%$; o-cymene, $15.4 \%$; and geraniol, $10.7 \%$ (Table 1 ).

Table 1. Chemical composition of essential oil of Thymus serpyllum.

\begin{tabular}{cccc}
\hline Number & $\mathbf{R I}^{\mathbf{a}}$ & Compound $^{\mathbf{b}}$ & $\mathbf{\%}^{\mathbf{c}}$ \\
\hline 1 & 858 & cis-hexen-1-ol & $\mathrm{Tr}$ \\
2 & 926 & $\alpha$-thujene & 0.5 \\
3 & 938 & $\alpha$-pinene & 1.2 \\
4 & 948 & camphene & 1.1 \\
5 & 976 & 1-octen-3-one & 0.8 \\
6 & 980 & $\beta$-pinene & 0.3 \\
7 & 992 & $\beta$-myrcene & 1.1 \\
8 & 993 & octan-3-ol & $\mathrm{Tr}$ \\
9 & 1004 & $\alpha$-phellandrene & $\mathrm{Tr}$ \\
10 & 1009 & --3-carene & $\mathrm{Tr}$ \\
11 & 1016 & $\alpha$-terpinene & 1.1 \\
12 & 1026 & 0 -cymene & 15.4 \\
13 & 1028 & $\alpha$-limonene & 1.2 \\
14 & 1033 & 1,8 -cineole & 1.5 \\
15 & 1060 & $\gamma$-terpinene & 8.1 \\
16 & 1088 & $\alpha$-terpinolene & $\mathrm{Tr}$ \\
\hline
\end{tabular}


Table 1. Cont.

\begin{tabular}{cccc}
\hline Number & $\mathbf{R I}^{\mathbf{a}}$ & Compound & $\mathbf{\%}^{\mathbf{c}}$ \\
\hline 17 & 1098 & Linalool & 5.3 \\
18 & 1148 & Camphor & 0.9 \\
19 & 1170 & Borneol & 2.3 \\
20 & 1178 & -terpineol & 1.8 \\
21 & 1235 & Thymol methyl ether & $\mathrm{Tr}$ \\
22 & 1241 & Carvone & $\mathrm{Tr}$ \\
26 & 1245 & Carvacrol methyl ether & 0.5 \\
27 & 1255 & Linalool acetate & 1.5 \\
28 & 1256 & Geraniol & 10.7 \\
29 & 1286 & Bornyl acetate & 0.6 \\
30 & 1290 & Thymol & 18.8 \\
31 & 1302 & Carvacrol & 17.4 \\
32 & 1353 & $\alpha$-cubebene & $\mathrm{Tr}$ \\
33 & 1360 & Eugenol & $\mathrm{Tr}$ \\
34 & 1379 & $\alpha$-copaene & $\mathrm{Tr}$ \\
35 & 1380 & Geranyl acetate & 4.4 \\
36 & 1406 & Methyl eugenol & $\mathrm{Tr}$ \\
37 & 1422 & cis-caryophyllene & 2.4 \\
38 & 1456 & $\alpha$-humulene & 1.0 \\
39 & 1443 & Aromadendrene & $\mathrm{Tr}$ \\
40 & 1507 & $\beta$-bisabolene & $\mathrm{Tr}$ \\
41 & 1525 & -cadinene & $\mathrm{Tr}$ \\
42 & 1583 & Caryophyllene oxide & 99.9 \\
& Total & &
\end{tabular}

a Values of retention indices on HP-5MS column; ${ }^{\mathrm{b}}$ identified compounds; ${ }^{\mathrm{c}}$ tr-compounds identified in amounts less than $0.1 \%$.

\subsection{Antioxidant and Antimicrobial Activity, and Minimum Inhibitory Concentrations (MIC)}

The antioxidant activity of T. serpyllum measured by the DPPH method was determined at $82.4 \pm 0.5 \%$ of inhibition which corresponds to $463.53 \pm 2.60$ TEAC. Weak antimicrobial activity of T. serpyllum EO was observed against $Y$. enterocolitica, S. aureus, and C. tropicalis. Moderate inhibitory activity was found against B. subtilis, E. faecalis, C. albicans, C. krusei, and C. glabrata. Other microorganisms, including biofilm-forming microorganisms, showed very strong inhibitory activity (Table 2). Using with MIC method, the lowest inhibitory concentrations were found against $S$. enteritidis, P. aeruginosa, and biofilm-forming bacteria. The highest inhibitory concentrations were identified against $Y$. enterocolitica, S. aureus, and C. tropicalis (Table 2).

Table 2. Antimicrobial activity of essential oil of T. serpyllum.

\begin{tabular}{|c|c|c|c|c|c|}
\hline Microorganism & $\begin{array}{l}\text { Inhibition } \\
\text { Zone (mm) }\end{array}$ & $\begin{array}{c}\text { Activity of } \\
\text { EO }\end{array}$ & $\begin{array}{c}\text { MIC } \\
50(\mu \mathrm{L} / \mathrm{mL})\end{array}$ & $\begin{array}{c}\text { MIC } \\
90(\mu \mathrm{L} / \mathrm{mL})\end{array}$ & $\begin{array}{c}\text { Activity } \\
\text { of EO }\end{array}$ \\
\hline Salmonella enteritidis & $15.67 \pm 1.53$ & $* * *$ & 0.39 & 0.78 & $* * *$ \\
\hline Pseudomonas aeruginosa & $30.33 \pm 0.58$ & $* * *$ & 0.20 & 0.39 & $* * *$ \\
\hline Yersinia enterocolitica & $6.33 \pm 0.58$ & * & 12.5 & 25.00 & * \\
\hline Staphylococcus aureus & $8.33 \pm 1.15$ & * & 12.5 & 25.00 & * \\
\hline Bacillus subtilis & $11.33 \pm 1.53$ & $* *$ & 6.25 & 12.50 & $* *$ \\
\hline Enterococcus faecalis & $13.67 \pm 1.53$ & $* *$ & 6.25 & 12.50 & $* *$ \\
\hline Candida albicans & $12.33 \pm 1.53$ & $* *$ & 1.56 & 3.13 & $* * *$ \\
\hline Candida krusei & $11.00 \pm 1.00$ & $* *$ & 3.13 & 6.25 & $* * *$ \\
\hline Candida tropicalis & $9.33 \pm 0.58$ & * & 12.5 & 25.00 & $*$ \\
\hline Candida glabrata & $11.00 \pm 1.00$ & $* *$ & 3.13 & 6.25 & $* * *$ \\
\hline Biofilm Stenotrophomonas maltophilia & $15.67 \pm 0.58$ & $* * *$ & 0.39 & 0.78 & $* * *$ \\
\hline Biofilm Bacillus subtilis & $25.33 \pm 0.58$ & $* * *$ & 0.20 & 0.39 & $* * *$ \\
\hline
\end{tabular}


2.3. Analysis of Biofilm Development and Molecular Differences Using the MALDI-TOF MS Biotyper

Figure 1 shows the spectra of developmental stages of $S$. maltophilia biofilm throughout the experiment.
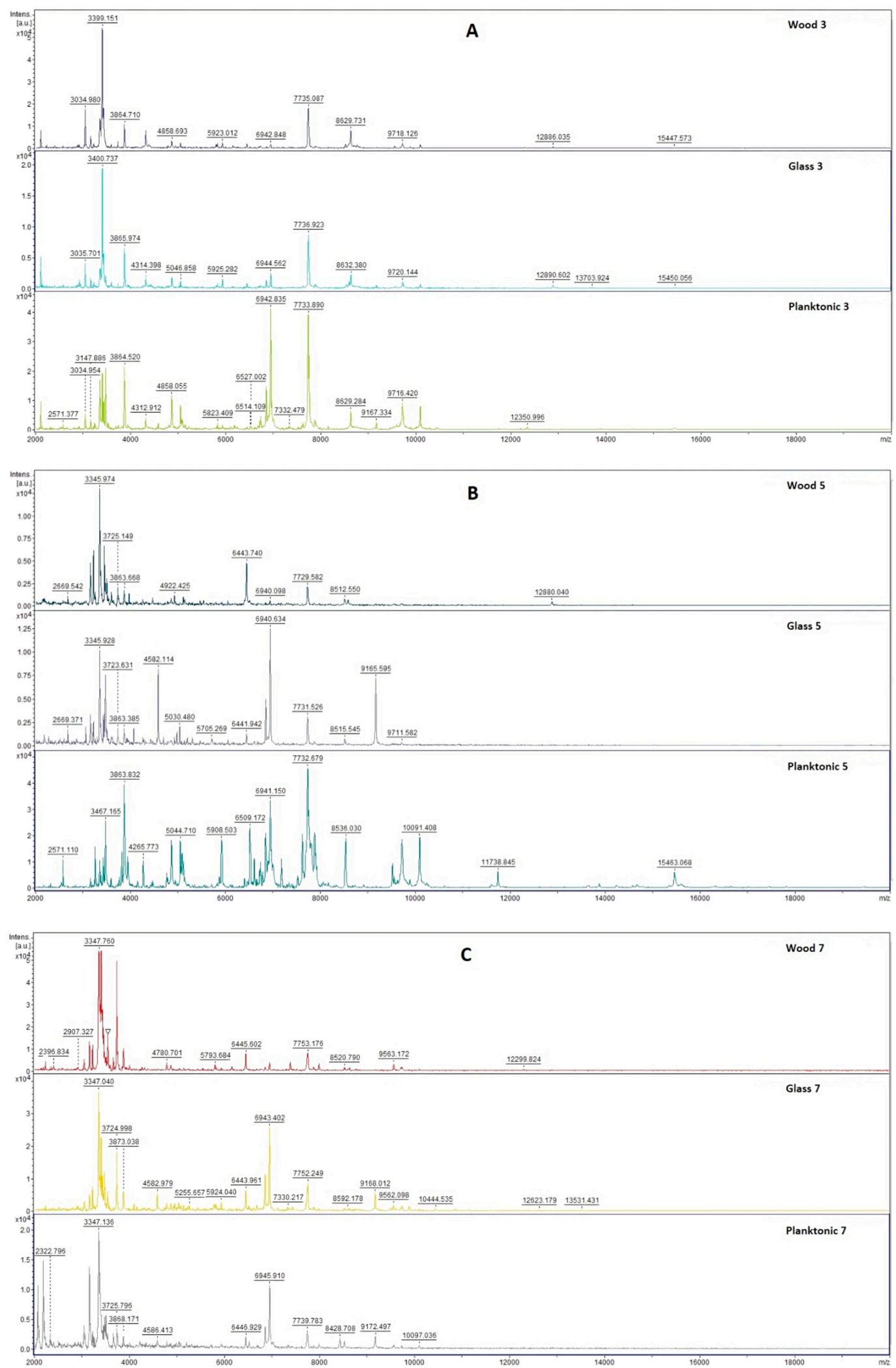

Figure 1. Cont. 

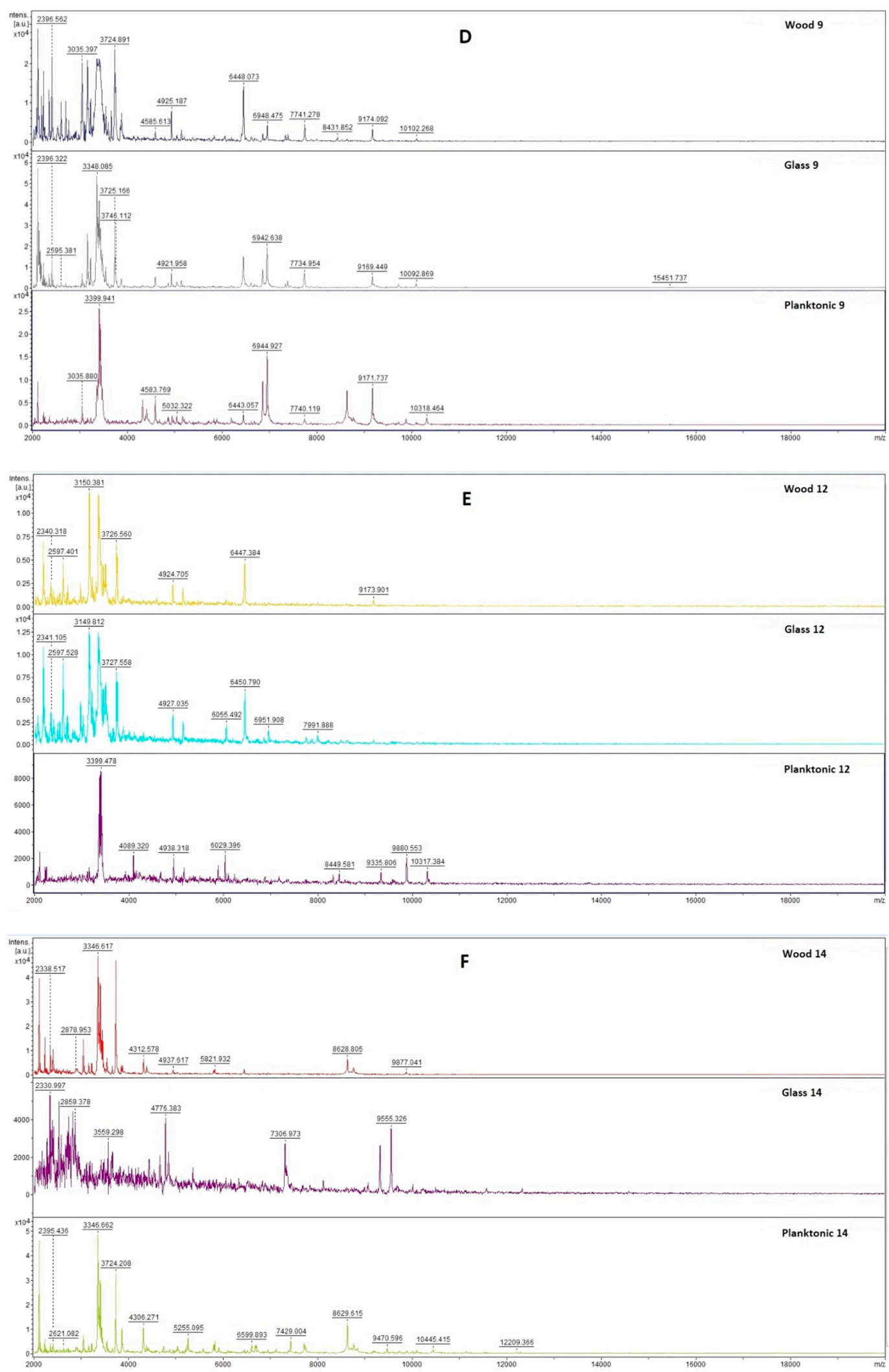

Figure 1. MALDI-TOF mass spectra of S. maltophilia biofilm during development: (A) 3rd day, (B) 5th day, (C) 7th day, (D) 9th day, (E) 12th day, and (F) 14th day.

The essential oil was evaluated according to the results of the mass spectra analysis of S. maltophilia with the addition of T. serpyllum EO. The spectra of control samples 
(planktonic bacteria and biofilm untreated with the EO) developed accurately (spectra not provided), thus the control planktonic cells were used as a control for comparison of biofilm structural changes.

Mass spectra after the 3rd day (Figure 1A) of cultivation showed the same peaks which indicates the same protein production by the young biofilms and the control planktonic cells. No changes in bacterial cultures were observed on the protein level.

The difference between mass spectra of biofilms on glass and wooden surfaces and the control sample occurred from the 5 th day (Figure 1B-F). There were visible changes in the protein profile of biofilm treated with the EO of T. serpyllum. It seems that T. serpyllum EO influences the homeostasis of bacterial biofilm formed on the wooden and the glass surface.

The dendrogram was constructed as a visualization of mass spectra for determination of some similarities of biofilm structure regarding the distance of the MSPs. It can be stated from the constructed dendrogram (Figure 2), that the planktonic stage (P) together with control groups and the young biofilms had the shortest distance from the 3rd day when it grew on the wood and the glass (SSM3 and DSM3, respectively). The similarity in protein profile of the control groups was confirmed by the short distances of the MSPs. The young biofilms and control planktonic cells also had short MSP distances which corresponded with the mass spectra. The distance of MSP experimental groups increased gradually over time. Mass spectra prepared on the 12th and 14th day of the experiment had the longest MSP distances which indicated the changes in the bacterial biofilm protein profile of S. maltophilia.

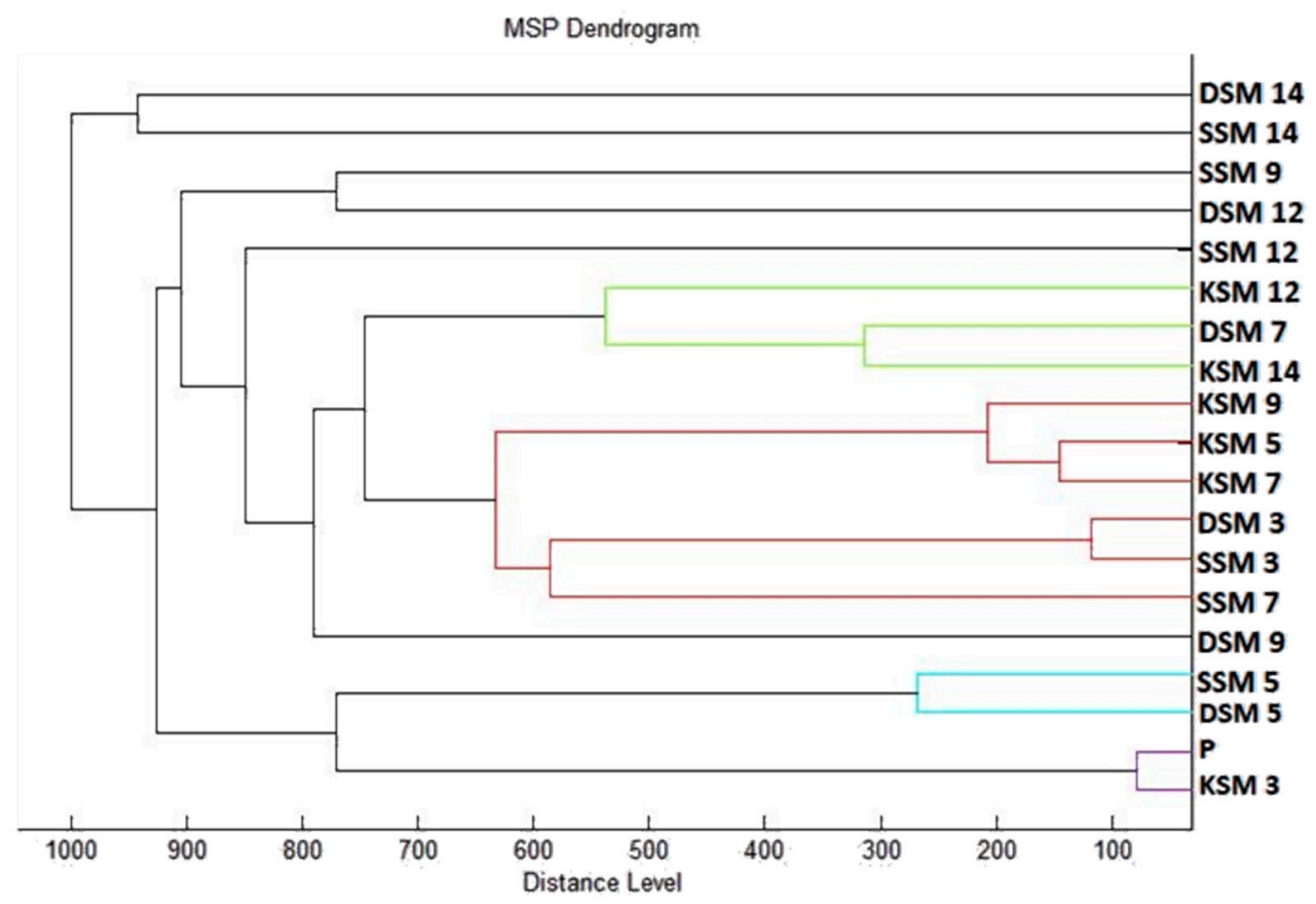

Figure 2. Dendrogram of S. maltophilia generated using MSPs of the planktonic cells and the control. SM, S. maltophilia; $\mathbf{K}$, control; S, glass; D, wood; and P, planktonic cells.

Figure 3 shows the spectra of developmental stages of B. subtilis biofilm over the entire duration of the experiment.

Mass spectral analysis of $B$. subtilis biofilm showed the similarity of the experimental spectra and the control planktonic spectrum on the 3rd day of the experiment (Figure 3A) which indicates that bacterial biofilm developed equally due to the protein production. 

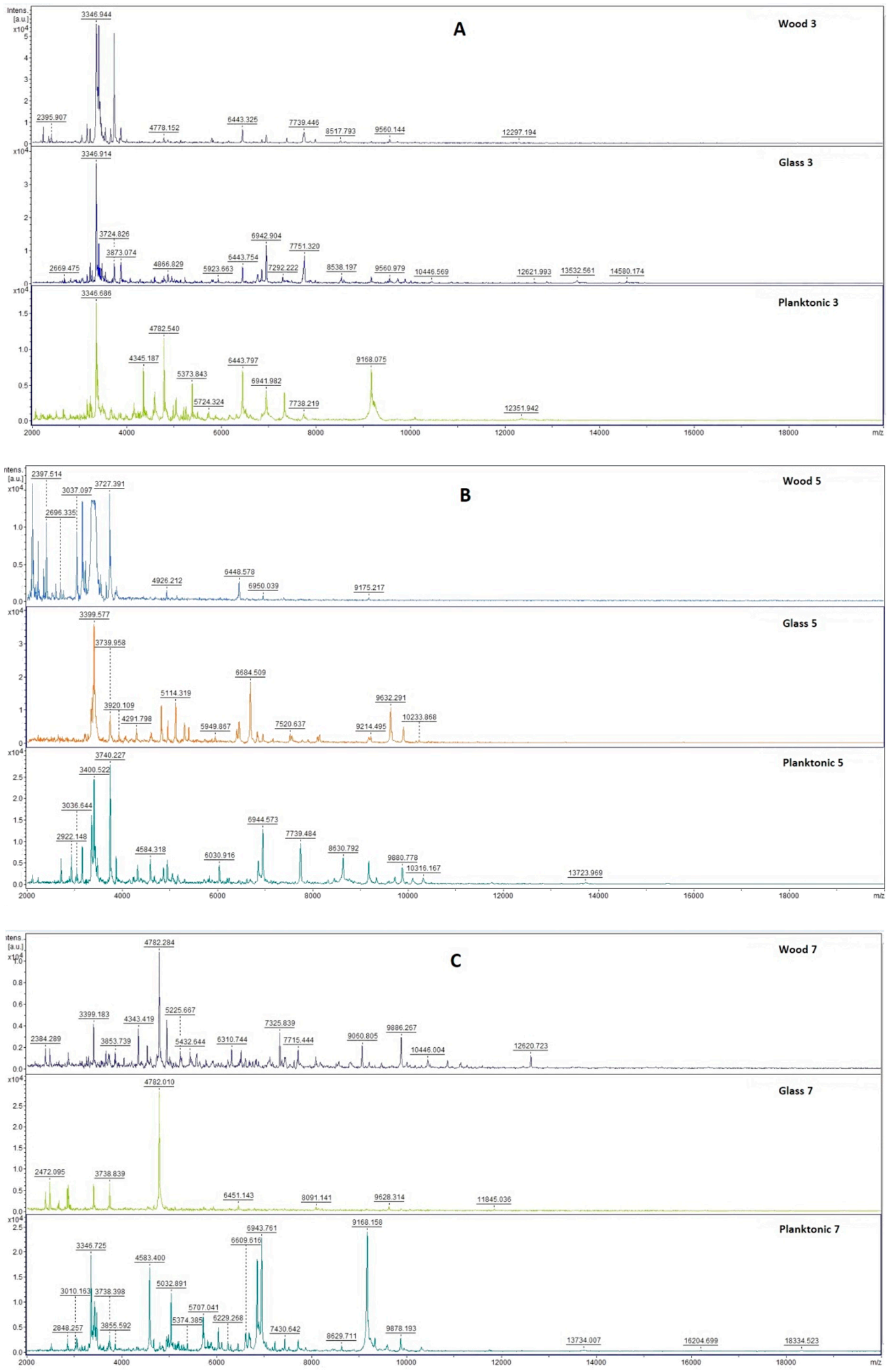

Figure 3. Cont. 

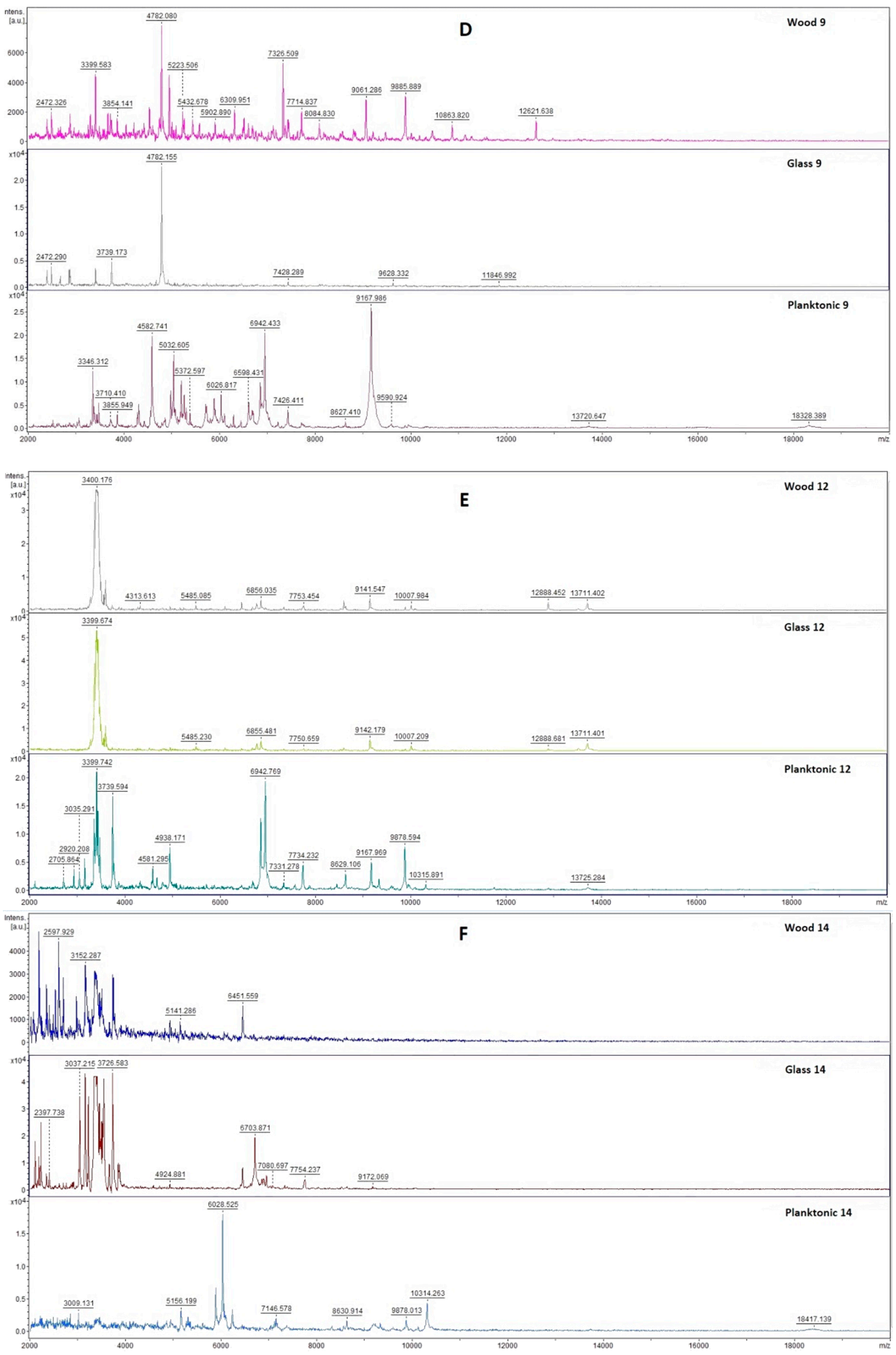

Figure 3. Representative MALDI-TOF mass spectra of B. subtilis: (A) 3rd day, (B) 5th day, (C) 7th day, (D) 9th day, (E) 12th day, and; (F) 14th day. 
The changes in mass spectra on 5th day were more visible on biofilm formed on wood than on the glass surface (Figure 3B). The changes in the mass spectra, in comparison to control planktonic cells, were observed in biofilm on both surfaces from 7th day (Figure 3C-F).

The changes in protein profile of $B$. subtilis biofilm treated with the EO of T. serpyllum were visible two days later than those of $S$. maltophilia. However, the effect of T. serpyllum EO on protein production can be confirmed in the biofilm-forming bacteria B. subtilis compared to untreated control cells.

The dendrogram constructed according to mass spectra also confirmed the similarity of young biofilms with planktonic cells and control cells. The distance of MSP growth during the experiment progression indicates the differences in protein production caused by influence of T. serpyllum $\mathrm{EO}$ addition (Figure 4).

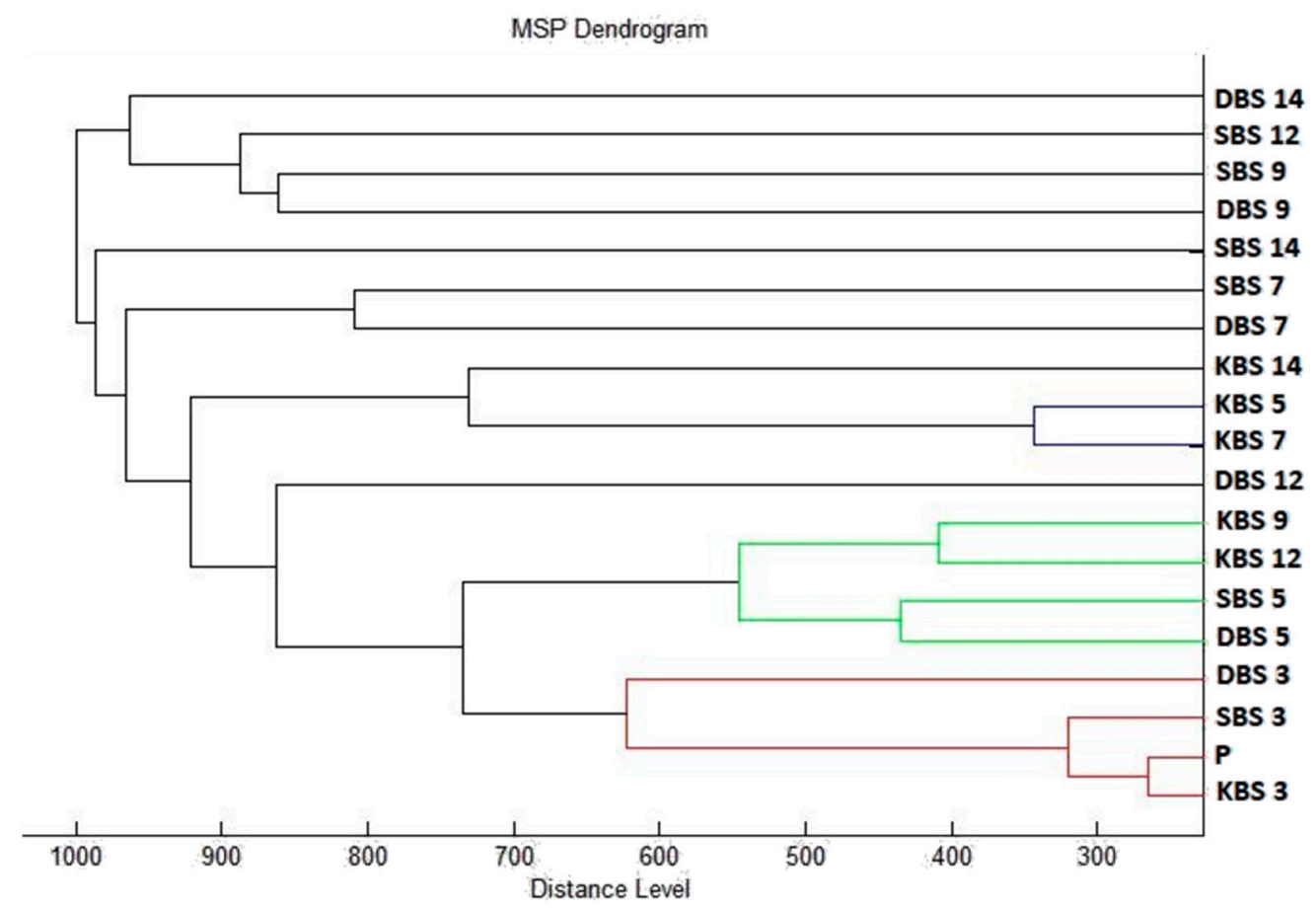

Figure 4. Dendrogram of B. subtilis generated using MSPs for the planktonic cells and the control. BS, B. subtilis; K, control; S, glass; D, wood; $\mathbf{P}$, planktonic cells.

\subsection{Antimicrobial Analysis of Bread in Situ}

The vapor phase of the antibacterial activity of T. serpyllum $\mathrm{EO}$ was confirmed at higher concentrations (Table 3). S. maltophilia was inhibited at concentrations of $250 \mu \mathrm{L} / \mathrm{L}$ and $500 \mu \mathrm{L} / \mathrm{L}$ by $83.51 \%$ and $44.05 \%$, respectively. B. subtilis was inhibited at concentrations of $125-500 \mu \mathrm{L} / \mathrm{L}$ while the highest inhibitory effect of up to $94.47 \%$ was achieved at $250 \mu \mathrm{L} / \mathrm{L}$. Antifungal activity against P. citrinum varied between $15.21 \%$ and $84.93 \%$. P. crustosum was inhibited to a lesser extent than the other fungi tested with the highest inhibition of $54.15 \%$ recorded at $500 \mu \mathrm{L} / \mathrm{L}$. P. expansum was the most effectively inhibited by the vapor phase of T. serpyllum with an inhibition of $84.93 \%$ at $125 \mu \mathrm{L} / \mathrm{L}$ (Table 3). 
Table 3. In situ analysis of the antibacterial activity of the vapor phase of T. serpyllum essential oil in bread.

\begin{tabular}{|c|c|c|c|c|}
\hline \multicolumn{5}{|c|}{ Bacterial Growth Inhibition (\%) } \\
\hline $\begin{array}{l}\text { Concentration of EO } \\
\text { Microorganisms }\end{array}$ & $62.5 \mu \mathrm{L} / \mathrm{L}$ & $125 \mu \mathrm{L} / \mathrm{L}$ & $250 \mu \mathrm{L} / \mathrm{L}$ & $500 \mu \mathrm{L} / \mathrm{L}$ \\
\hline S. maltophilia & $11.13 \pm 0.88$ & $-55.51 \pm 2.07$ & $44.05 \pm 1.08$ & $83.51 \pm 0.54$ \\
\hline B. subtilis & $-12.38 \pm 1.22$ & $30.50 \pm 1.76$ & $94.47 \pm 2.73$ & $84.21 \pm 1.83$ \\
\hline \multicolumn{5}{|c|}{ Mycelial Growth Inhibition (\%) } \\
\hline $\begin{array}{l}\text { Concentration of EO } \\
\text { Microorganisms }\end{array}$ & $62.5 \mu \mathrm{L} / \mathrm{L}$ & $125 \mu \mathrm{L} / \mathrm{L}$ & $250 \mu \mathrm{L} / \mathrm{L}$ & $500 \mu \mathrm{L} / \mathrm{L}$ \\
\hline P. citrinum & $84.93 \pm 1.11$ & $58.93 \pm 1.97$ & $73.27 \pm 2.07$ & $73.51 \pm 1.33$ \\
\hline P. crustosum & $15.21 \pm 0.43$ & $42.63 \pm 1.54$ & $48.85 \pm 2.63$ & $54.15 \pm 1.46$ \\
\hline P. expansum & $34.34 \pm 2.41$ & $84.93 \pm 0.55$ & $77.65 \pm 1.89$ & $66.26 \pm 1.42$ \\
\hline
\end{tabular}

\subsection{In Situ Antimicrobial Analysis of Carrots}

Inhibition of $S$. maltophilia was recorded on carrots at all concentrations with the highest inhibition rate of $83.77 \%$ at $500 \mu \mathrm{L} / \mathrm{L}$ and the lowest of $3.90 \%$ at $62.5 \mu \mathrm{L} / \mathrm{L}$ (Table 4 ). The growth of $B$. subtilis was inhibited on carrots equally at all concentrations. The highest inhibition was $72.46 \%$ at $500 \mu \mathrm{L} / \mathrm{L}$ and the lowest was $41.67 \%$ at $125 \mu \mathrm{L} / \mathrm{L}$. The antifungal activity of the vapor phase of T. serpyllum EO against $P$. citrinum was $63.27 \%$ at a concentration of $125 \mu \mathrm{L} / \mathrm{L}$. P. crustosum was inhibited at all concentrations but the highest inhibition was $53.82 \%$ at a concentration of $125 \mu \mathrm{L} / \mathrm{L}$. The highest inhibition of P. expansum was 39.03\% at $125 \mu \mathrm{L} / \mathrm{L}$.

Table 4. Results of in situ analysis of antibacterial activity of the vapor phase of T. serpyllum essential oil on carrots.

\begin{tabular}{|c|c|c|c|c|}
\hline \multicolumn{5}{|c|}{ Bacterial Growth Inhibition (\%) } \\
\hline $\begin{array}{l}\text { Concentration of EO } \\
\text { Microorganisms }\end{array}$ & $62.5 \mu \mathrm{L} / \mathrm{L}$ & $125 \mu \mathrm{L} / \mathrm{L}$ & $250 \mu \mathrm{L} / \mathrm{L}$ & $500 \mu \mathrm{L} / \mathrm{L}$ \\
\hline S. maltophilia & $3.39 \pm 0.09$ & $25.72 \pm 1.78$ & $6.07 \pm 1.32$ & $83.77 \pm 0.66$ \\
\hline B. subtilis & $42.92 \pm 1.11$ & $41.67 \pm 2.09$ & $47.15 \pm 0.24$ & $72.46 \pm 2.07$ \\
\hline \multicolumn{5}{|c|}{ Mycelial Growth Inhibition (\%) } \\
\hline $\begin{array}{l}\text { Concentration of EO } \\
\text { Microorganisms }\end{array}$ & $62.5 \mu \mathrm{L} / \mathrm{L}$ & $125 \mu \mathrm{L} / \mathrm{L}$ & $250 \mu \mathrm{L} / \mathrm{L}$ & $500 \mu \mathrm{L} / \mathrm{L}$ \\
\hline P. citrinum & $-7.50 \pm 0.88$ & $63.27 \pm 0.27$ & $9.25 \pm 1.75$ & $-7.50 \pm 0.73$ \\
\hline P. crustosum & $44.20 \pm 1.33$ & $53.82 \pm 0.86$ & $23.24 \pm 1.92$ & $25.80 \pm 1.01$ \\
\hline P. expansum & $0.85 \pm 0.09$ & $39.03 \pm 1.45$ & $8.75 \pm 0.49$ & $16.90 \pm 0.61$ \\
\hline
\end{tabular}

\section{Discussion}

The authors of previously published studies agreed that thymol, cymene, and carvacrol were the most common major components of T. serpyllum essential oil. The compounds thymol and carvacrol are known for their potential antimicrobial and antifungal activity [12]. Nikolić et al. [13] identified oxygenated monoterpenes, 54.5\%; thymol, 38.5\%; monoterpene hydrocarbons, $26.3 \%$; and $p$-cymene, $8.9 \%$ as the main compounds of the EO of T. serpyllum. The authors state that T. serpyllum is very suitable for use in the food industry for food preservation and in the pharmaceutical industry because of its high thymol content. Baj et al. [14] in their study found major compounds such as linalool, 30.9\%; thymol, 25.1\%; and geraniol, $10.5 \%$. T. serpyllum is a suitable alternative to artificial fungicides because of the high content of monoterpene compounds. Kovacevic et al. [15] determined the main compounds of T. serpyllum EO to be thymol, $54.17 \%$; $\gamma$-terpinene, $22.18 \%$; and p-cymene $16.66 \%$. Thymol $(15.21 \%$ and $41.8 \%)$ was the main compound of T. serpyllum EO in the studies of Šojić et al. [16] and Tazabayeva and Sylibaeva [17]. Pruteanu et al. [18] 
also found that thymol, $36.30 \%$; o-cymene, $24.98 \%$; and hydroquinone tert-butyl, $10.25 \%$ were the main components of T. serpyllum EO. Our results are in line with above-listed authors. T. serpyllum is suitable for use in food preservation due to the dominant presence of thymol and carvacrol in its EO. The differences in the content of the main compounds in previous studies could be attributed to different origins of the EO. T. vulgaris or T. zygis had minimum thymol and carvacrol contents of 40\% [19] which was similar to the results of our study. The Council of Europe and European Medicines Agency Assessment Report lists concentrations of thyme EO as $37-55 \%$ thymol and $0.5-5.5 \%$ carvacrol, what is higher in comparison with our study $[19,20]$.

The method for DPPH radical scavenging is variable in terms of solvent, incubation time, ratio of sample, and DPPH solution which makes the proper comparison of the present results with previous studies more difficult. Nikolić et al. [13] determined DPPH scavenging activity of T. serpyllum EO with different ratios of the sample and DPPH. With $30 \mu \mathrm{L}$ of sample and $270 \mu \mathrm{L}$ of DPPH the results were determined as EC 50 at a value $0.96 \mu \mathrm{g}$ Trolox $/ \mathrm{mL}$; thus the activity of T. serpyllum EO was strong. Kulisic et al. [21] detected the percentage of inhibition of T. serpyllum EO oil at $82.00 \pm 0.07 \%$ for DPPH and the sample in ethanol, and antioxidant activity was considered as strong. Hussain et al. [22] determined the antioxidant activity value as IC50 at $34.8 \pm 1.9 \mu \mathrm{g} / \mathrm{mL}$ after incubation for $1 \mathrm{~h}$ which was evaluated as good activity. All authors concluded that the antioxidant activity of T. serpyllum EO is strong that supports our results despite of the variations in method and the differences in the results.

Hussain et al. [22] found a strong antimicrobial effect of T. serpyllum against human, plant, and foodborne pathogens using the disc diffusion method. They determined strong inhibitory activity for various microorganisms. The inhibition zones for microorganisms were slightly higher-S. aureus $(20.2 \pm 0.7 \mathrm{~mm})$, B. subtilis $(27.2 \pm 0.9 \mathrm{~mm})$, P. aeruginosa $(16.2 \pm 0.6 \mathrm{~mm})$, and Salmonella sp. $(20.8 \pm 0.5 \mathrm{~mm})$ —compared with our study. Goja et al. [23] confirmed the strong antimicrobial activity of T. serpyllum with inhibition zones of $S$. aureus, $34 \pm 1 \mathrm{~mm}$; P. aeruginosa, $7 \pm 1 \mathrm{~mm}$; and C. albicans, $26 \pm 1 \mathrm{~mm}$. Thymus serpyllum $\mathrm{EO}$ is suitable as a source of natural food additives due to its diverse antimicrobial effect. Ouedrhiri et al. [24] identified antimicrobial activity of T. serpyllum with inhibition zones for S. aureus of $36.00 \pm 1.73 \mathrm{~mm}$, B. subtilis of $33.00 \pm 2.64 \mathrm{~mm}$, and P. aeruginosa of $10.00 \pm 1.73 \mathrm{~mm}$. T. serpyllum $\mathrm{EO}$ showed strong bactericidal activity against a diverse range of microorganisms; it contains increased thymol content, which can be responsible for the antibacterial effect. Ouedrhiri et al. [24] determined the MICs of T. serpyllum EO for S. aureus, $0.25 \mu \mathrm{L} / \mathrm{mL}$; B. subtilis, $0.125 \mu \mathrm{L} / \mathrm{mL}$; and P. aeruginosa, $4 \mu \mathrm{L} / \mathrm{mL}$. These values are low and confirm the strong antimicrobial effect of T. serpyllum. MIC 50 and MIC 90 were $2 \pm 0.2 \mu \mathrm{L} / \mathrm{mL}$ and $4 \pm 0.3 \mu \mathrm{L} / \mathrm{mL}$ for C. albicans in the study by Nikolić et al. [13]. The determination of a low minimum concentration for $C$. albicans corresponds to our findings on the effect of T. serpyllum against the genus Candida. Wesołowska et al. [25] determined MICs of $0.78 \mu \mathrm{L} / \mathrm{mL}$ for S. aureus and of $1.56 \mu \mathrm{L} / \mathrm{mL}$ for E. faecalis. This finding indicates the possible use of T. serpyllum $\mathrm{EO}$ as an antimicrobial for food preservation and for the prevention of bacterial and fungal infections. Inhibitory activity was reported in the study by Hussain et al. [22] where MICs of $0.160 \pm 0.003 \mu \mathrm{L} / \mathrm{mL}$ for S. aureus, $1.25 \pm 0.034 \mu \mathrm{L} / \mathrm{mL}$ for P. aeruginosa, and $0.83 \pm 0.02 \mu \mathrm{L} / \mathrm{mL}$ for Salmonella spp. were found. It is known that T. serpyllum is considered as a suitable alternative to synthetic antimicrobials which confirms our findings.

The changes in MALDI-TOF mass spectra of treated and untreated sample were visible show the differences in protein production. Various research has proposed the abnormalities in protein production related to biofilm formation and degradation after EO addition. Nazzaro et al. [26] described the mechanisms of action of the EOs in damaging cell components and cell mechanisms, and in protein degradation. Szabó et al. [27] considered that EOs affect the quorum sensing in biofilm-forming bacteria, that could lead to changes in the cell at the protein level. Camele et al. [28] described that the quorum sensing mechanism is deteriorated by the influence of EOs and that disrupting the quorum sensing mechanism 
can help to prevent biofilm formation. Moreover, the differences in protein production of bacteria stressed with EOs was evaluated with MALDI-TOF MS by Božik et al. [29] demonstrating that EOs affect the production of ribosomal proteins and stress-related, membrane-related, and biofilm-related proteins.

The use of MALDI-TOF for detection of degradation of biofilm has been previously less reported. Kırmusaoğlu [30] described various methods for biofilm detection and stated that mass spectrometry is a less common but very suitable method for biofilm research. Stîngu et al. [31] described the accuracy of identification of biofilm-forming bacteria by MALDI-TOF MS compared to $16 \mathrm{~S}$ rRNA sequencing and confirmed that MALDI-TOF MS can distinguish the differences in the mass spectra of closely related biofilms. Gaudreau et al. [32] analyzed 18 biofilm-producing species by MALDI-TOF MS. They were able to identify $72 \%$ of bacteria at species level and $83 \%$ at genus levels with high confidence. Aguiar et al. [33] detected specific biofilm proteins with MALDI-TOF MS and suggested the suitability of using MALDI-TOF MS for biofilm-forming yeast detection. Kačániová et al. [34,35] demonstrated the changes in protein profile analysed by MALDI-TOF MS in their previous studies and the inhibitory effects of Coriandrum sativum and Citrus aurantium EOs on antimicrobial activity and biofilm formation. The inhibitory activity of EOs can support the idea that the changes in protein spectra could be connected with the structural and molecular changes of biofilm formation, growth, and degradation so MALDI-TOF MS can be used for these analyses. These findings correspond with current results. We can also confirmed that the structural changes of biofilm are well detected and MALDI-TOF MS can be used for detection of the changes in the protein profile of biofilm. The mechanisms of action of T. serpyllum EO at the protein level could be the main topic of further research.

The confirmed antibacterial effect of T. serpyllum shows the potential for it to be used in the storage of carrots and it could be considered as a natural alternative to chemical inhibition of Penicillium growth on bread. The effect in the vapor phase was described in the report by Střelková et al. [36]. Feng et al. [37] tested the antifungal effect and found that the vapor phase treatment is more efficient, faster, and easier to use in comparison to soaking.

The direct contact of Eos on microorganisms has often been studied in the past. Direct contact has demonstrated the antimicrobial effect of many EOs. There are only a few studies on the use of the vapor phase of EOs for the inhibition of microorganisms. S. maltophilia was inhibited at concentrations of $250 \mu \mathrm{L} / \mathrm{L}$ and $500 \mu \mathrm{L} / \mathrm{L}$. B. subtilis was inhibited at concentrations of $125-500 \mu \mathrm{L} / \mathrm{L}$. In correspondence with our results, a significant antimicrobial effect of thymus EO in the vapor phase was observed against several pathogenic bacteria [38-42]. The antifungal activity against $P$. citrinum varied from $15.21 \%$ to $84.93 \%$. P. crustosum was inhibited to a lesser extent than the other fungi tested with the highest inhibition of $54.15 \%$ at $500 \mu \mathrm{L} / \mathrm{L}$. P. expansum was the most effectively inhibited by the vapor phase of T. serpyllum with $84.93 \%$ inhibition at $125 \mu \mathrm{L} / \mathrm{L}$. The different dose of essential oils that are effective against different microscopic fungi were found in several studies [43-47]. These doses varied from 40 to $300 \mu \mathrm{L} / \mathrm{L}$ against Mucor, Rhizopus, as well as Penicillium and Aspergillus.

\section{Materials and Methods}

\subsection{Essential Oil}

Thymus serpyllum EO was purchased from Hanus, s.r.o. (Nitra, Slovakia) and was prepared by steam distillation of dried flowering stalk. It was stored in the dark at $4{ }^{\circ} \mathrm{C}$ throughout the analyses.

\subsection{Tested Microorganisms}

Microorganisms (Bacillus subtilis CCM 2772, Pseudomonas aeruginosa CCM 1959, Yersinia enterocolitica CCM 5671, Staphylococcus aureus subsp. aureus CCM 2461, Enterococcus faecalis CCM 4224, Salmonella enteritidis subsp. enteritidis CCM 4420, Candida krusei CCM 8271, 
Candida albicans CCM 8186, Candida tropicalis CCM 8223, and Candida glabrata CCM 8270) were obtained from the Czech collection of microorganisms. The biofilm-forming bacteria Bacillus subtilis and Stenotrophomonas maltophilia were obtained from the dairy industry and identified with 16S rRNA sequencing and MALDI-TOF MS Biotyper. There were three types of fungi isolated from grape samples, Penicillium expansum (from Rheinriesling), Penicillium crustosum (from Alibernet), and Penicillium citrinum (from Dornfelder). These fungi were identified with $16 \mathrm{~S}$ rRNA sequencing and MALDI-TOF MS Biotyper.

\subsection{Chemical Characterization of Essential Oil Samples by Gas Chromatography/Mass Spectrometry (GC/MS) and Gas Chromatography (GC-FID)}

GC/MS analysis of selected essential oil samples was performed using an Agilent $6890 \mathrm{~N}$ gas chromatograph (Agilent Technologies, Santa Clara, CA, USA) coupled to a quadrupole mass spectrometer 5975B (Agilent Technologies, Santa Clara, CA, USA) with an HP-5MS capillary column $(30 \mathrm{~m} \times 0.25 \mathrm{~mm} \times 0.25 \mu \mathrm{m})$. The temperature program was $60{ }^{\circ} \mathrm{C}$ to $150{ }^{\circ} \mathrm{C}$ (increasing rate, $3{ }^{\circ} \mathrm{C} / \mathrm{min}$ ) and $150{ }^{\circ} \mathrm{C}$ to $280{ }^{\circ} \mathrm{C}$ (increasing rate, $5^{\circ} \mathrm{C} / \mathrm{min}$ ). The total run time was $60 \mathrm{~min}$. Helium 5.0 was used as the carrier gas with flow rate of $1 \mathrm{~mL} / \mathrm{min}$. The injection volume was $1 \mu \mathrm{L}$ (the EO sample was diluted in pentane), while the split/splitless injector temperature was set at $280^{\circ} \mathrm{C}$. The investigated sample was injected in the split mode with split ratio at 40.8:1. Electron-impact mass spectrometric data (EI-MS; $70 \mathrm{eV}$ ) were acquired in scan mode over the $\mathrm{m} / \mathrm{z}$ range $35-550$. The MS ion source and MS quadrupole temperatures were $230^{\circ} \mathrm{C}$ and $150{ }^{\circ} \mathrm{C}$, respectively. Acquisition of data started after a solvent delay time of $3 \mathrm{~min}$. GC-FID analyses were performed on an Agilent $6890 \mathrm{~N}$ gas chromatograph coupled to a FID detector. The column (HP-5MS) and chromatographic conditions were the same as for GC-MS. The temperature of the FID detector was set at $300^{\circ} \mathrm{C}$.

The individual volatile constituents of injected essential oil samples were identified according to their retention indices [48] and they were compared with the reference spectra (Wiley and NIST databases). The retention indices were experimentally determined by the standard method described in the study by Van Den Dool and Kratz [49], which included retention times of n-alkanes (C6-C34), injected under the same chromatographic conditions. The percentages of the identified compounds (amounts higher than $0.1 \%$ ) were derived from their GC peak areas.

\subsection{Antioxidant Activity-DPPH Method}

This method is based on colorimetric reaction where 2,2-diphenyl-1-picrylhydrazyl (DPPH, Sigma Aldrich, Germany) changes its color from purple to light yellow due to reaction with antioxidant. Analysis was carried out in a 96-well microplate. The DPPH working solution was prepared from stock solution $(0.0025 \mathrm{~g} / \mathrm{L}$ of DPPH in methanol) and it was diluted ten times. Absorbance was adjusted to 0.7 at wavelength $515 \mathrm{~nm}$. A calibration curve was prepared with standard solution of Trolox (Sigma Aldrich, Schnelldorf, Germany) dissolved in methanol (Uvasol ${ }^{\circledR}$ for spectroscopy, Merck, Darmstadt, Germany) in the concentration range $0-100 \mu \mathrm{g} / \mathrm{mL}$ with $5 \mu \mathrm{L}$ of essential oil added to $195 \mu \mathrm{L}$ of DPPH working solution. Blank measurement was prepared by $200 \mu \mathrm{L}$ of DPPH. The calibration solution was prepared by addition of $5 \mu \mathrm{L}$ of Trolox solution with corresponding concentration to $195 \mu \mathrm{L}$ of DPPH working solution [50]. The microplate was incubated for $30 \mathrm{~min}$ on a shaker (IKA Inc., Staufen im Breisgau, Germany) at $200 \mathrm{rpm}$ in the dark and studied at $515 \mathrm{~nm}$ with a Glomax spectrophotometer (Promega Inc., Madison, WI, USA). The percentage of inhibition was calculated as $(\mathrm{A} 0-\mathrm{AA}) / \mathrm{A} 0 \times 100$, where $\mathrm{A} 0$ was absorbance of the blank measurement and AA was absorbance of the sample. Antioxidant activity was expressed as antioxidant activity of Trolox related to $1 \mathrm{~mL}$ of sample (TEAC).

\subsection{Antimicrobial Activity—Disc Diffusion Method}

Antimicrobial activity of T. serpyllum EO was determined using the disc diffusion method. Bacteria were aerobically cultivated on Tryptone Soya Agar (TSA, Oxoid, Basingstoke, UK) at $37^{\circ} \mathrm{C}$ for $24 \mathrm{~h}$, yeast at $25^{\circ} \mathrm{C}$ for $24 \mathrm{~h}$. An inoculum with an optical density 
of $0.5 \mathrm{McF}$ arland standard (corresponding to $1.5 \times 108 \mathrm{CFU} / \mathrm{mL}$ ) was prepared and an amount of $100 \mu \mathrm{L}$ was used for Mueller Hinton agar (MHA, Oxoid, Basingstoke, UK) inoculation. Clean discs with $6 \mathrm{~mm}$ diameter were saturated with $10 \mu \mathrm{L}$ of T. serpyllum EO and placed on the agar. Bacteria were incubated aerobically at $37^{\circ} \mathrm{C}$ for $24 \mathrm{~h}$ and yeast were incubated at $25^{\circ} \mathrm{C}$ for $24 \mathrm{~h}$. Criteria for detection of inhibitory activity were: an inhibition zone diameter above $5 \mathrm{~mm}$-weak inhibitory activity, above $10 \mathrm{~mm}$-moderate inhibition, and above $15 \mathrm{~mm}$ - very strong inhibition. Each test was repeated three times.

\subsection{Minimum Inhibitory Concentrations (MIC)}

Microorganisms were aerobically cultured for $24 \mathrm{~h}$ in Mueller Hinton Broth (MHB, Oxoid, Basingstoke, UK) at $37{ }^{\circ} \mathrm{C}$ for bacteria and at $25^{\circ} \mathrm{C}$ for yeasts. The $50 \mu \mathrm{L}$ of microbial suspension with optical density $0.5 \mathrm{McF}$ arland standard was applied to a 96-well microtiter plate. The amount of $100 \mu \mathrm{L}$ of MHB with T. serpyllum EO in concentrations from $400 \mu \mathrm{L} / \mathrm{mL}$ to $0.2 \mu \mathrm{L} / \mathrm{mL}$, prepared with serial dilution, was added to sample. The contents of the wells were mixed by pipetting. The MHB and EO were used as a negative control, and the MHB with inoculum was used as positive control of the maximal growth.

The MIC of biofilms was measured after $24 \mathrm{~h}$ with use of crystal violet. The suspension with non-attached cells was discarded and wells were washed with distilled water three times, dried at room temperature, stained with crystal violet $(200 \mu \mathrm{L} 0.1 \%(w / v))$ for $15 \mathrm{~min}$, and repeatedly washed and dried. Stained biofilms were resolubilized with $200 \mu \mathrm{L}$ of 33\% acetic acid [51]. Absorbance was measured at $570 \mathrm{~nm}$ (Glomax spectrophotometer, Promega Inc., Madison, WI, USA). The concentration of EO which had absorbance lower than the absorbance of the maximal growth control was determined as the minimum inhibitory concentration. Each test had three replications.

\subsection{Analysis of Differences in Biofilm Development with MALDI-TOF MS Biotyper}

The various phases of biofilm development were evaluated with MALDI-TOF MS Biotyper. S. maltophilia was used as a representative of Gram-negative biofilm-forming bacteria and B. subtilis was representative of Gram-positive biofilm-forming bacteria and both bacterial strains were isolated from the milk industry. The main goal was to monitor changes in the structure of the biofilm on glass and wooden surfaces after treatment with EO of T. serpyllum. Experimental and control samples were prepared in $50 \mathrm{~mL}$ polypropylene tubes with $20 \mathrm{~mL}$ of $\mathrm{MHB}$, a wooden toothpick, and a glass slide. The experimental groups contained $\mathrm{MHB}$ enriched with $0.5 \%$ T. serpyllum $\mathrm{EO}$ and inoculated samples were incubated at $37^{\circ} \mathrm{C}$ on a slope $45^{\circ}$ shaker at $170 \mathrm{rpm}$. Biofilm and planktonic cell samples were analysed on days $3,5,7,9,12$, and 14 . The biofilm samples were taken from a glass slide and wooden toothpick using a sterile cotton swab and imprinted onto a MALDITOF metal target plate on certain day. The planktonic cells were obtained by removing $300 \mu \mathrm{L}$ of culture medium. The culture medium was centrifuged for $1 \mathrm{~min}$ at 12,000 rpm. The supernatant was discarded, the planktonic cells were washed three times with ultrapure water. The pellet was resuspended in $30 \mu \mathrm{L}$ of ultrapure water and centrifuged for $1 \mathrm{~min}$ at $12,000 \mathrm{rpm}$. The planktonic cells were resuspended and $1 \mu \mathrm{L}$ of the suspension was applied to a target plate after washing. The amount of $1 \mu \mathrm{L}$ of $\alpha$-Cyano-4-hydroxycinnamic acid matrix $(10 \mathrm{mg} / \mathrm{mL})$ was applied to biofilm and planktonic cell samples and dried at room temperature. The samples were processed with MALDI-TOF MicroFlex (Bruker Daltonics) linear and positive mode for the range of m/z 200-2000 after crystallization. The spectra were obtained by an automatic analysis and the same sample similarities were used to generate the standard global spectrum (MSP). Nineteen MSP from the spectra generated by the MALDI Biotyper 3.0 were grouped into dendrograms using Euclidean distance [35].

\subsection{Antimicrobial Analysis of Bread In Situ}

The in situ antimicrobial effects of T. serpyllum $\mathrm{EO}$ against biofilm-forming bacteria (S. maltophilia and B. subtilis) and fungi (Penicillium spp.) were analyzed on bread in order 
to inhibit food degradation by pathogens. The bread was sliced $(15 \times 15 \times 1.5 \mathrm{~cm})$ and placed in 0.5 L sterile glass jars (Bormioli Rocco, Parma, Italy). Biofilm-forming bacteria were cultured for $24 \mathrm{~h}$ at $37^{\circ} \mathrm{C}$ on Tryptone Soya agar (TSA, Oxoid, Basingstoke, UK) and Penicillium on Sabouraud Dextrose agar (SDA, Oxoid, Basingstoke, UK) at $25^{\circ} \mathrm{C}$ for 5 days before inoculation. The inoculum was applied to the bread by three stabs. A sterile filter paper $(6 \mathrm{~cm}$ in diameter) was placed under the jar lid and $100 \mu \mathrm{l}$ of T. serpyllum EO (62.5, 125,250 , and $500 \mu \mathrm{L} / \mathrm{L}+$ ethyl acetate) were applied. The control group of bread was without EO treatment. The jars were hermetically sealed and maintained at $25^{\circ} \mathrm{C} \pm 1{ }^{\circ} \mathrm{C}$ for 14 days in the dark.

In situ bacterial growth was determined using stereological methods. In this concept, the volume density $(\mathrm{Vv})$ of bacterial colonies was firstly estimated using ImageJ software counting the points of the stereological grid hitting the colonies $(\mathrm{P})$ and those $(\mathrm{p})$ falling to the reference space (growth substrate used). The volume density of bacterial colonies was consequently calculated as follows: $\mathrm{Vv}(\%)=\mathrm{P} / \mathrm{p}$. The antibacterial activity of EO was defined as the percentage of bacterial growth inhibition (BGI) BGI $=[(C-T) / C] \times 100$, where $C$ and $\mathrm{T}$ were bacterial growth (expressed as $\mathrm{Vv}$ ) in the control group and the treatment group, respectively. The negative results represented the growth stimulation.

The size of microfungal colonies with visible growth and sporulation was assessed with stereological methods. In this concept, the volume density of the colonies was firstly assessed using ImageJ software counting the points of the stereological grid hitting the colonies and those falling to the reference space (growth substrate used). EO antifungal activity was expressed as mycelial growth inhibition in \% (MGI): MGI $=[(C-T) / C] \times 100$, where $C$ was fungal growth (expressed as volume density) in the control group and $\mathrm{T}$ was the growth in the treatment group [52,53].

\subsection{In Situ Antimicrobial Analysis on Carrots}

In situ antimicrobial analysis in the vapor phase was tested on biofilm-forming bacteria S. maltophilia and B. subtilis and fungi Penicillium spp. Warm MHA was poured into $60 \mathrm{~mm}$ petri dishes (PD) and the lid. Sliced carrots $(0.5 \mathrm{~mm})$ were placed on agar. Then, an inoculum was prepared as previously described. T. serpyllum $\mathrm{EO}$ was diluted twice in ethyl acetate to $500,250,125$, and $62.5 \mu \mathrm{L} / \mathrm{L}$ and used for sterile filter paper inoculation. The filter paper was placed in for $1 \mathrm{~min}$ to evaporate the remaining ethyl acetate, sealed and incubated for at $37^{\circ} \mathrm{C}$ for 7 days and for fungi at $25^{\circ} \mathrm{C}$ for 14 days. Growth assessment was performed as in the in situ antimicrobial activity method.

\subsection{Statistical Data Evaluation}

$\mathrm{SAS}^{\circledR}$ software used for data processing. The results of the MIC value (concentration that caused 50\% and 90\% inhibition in bacterial growth) were determined by logit analysis.

\section{Conclusions}

The MALDI-TOF MS Biotyper used for the first time in analyses of a biofilm formed by S. maltophilia and B. subtilis as contaminant in the food industry in our study. The inhibition of the biofilm after T. serpyllum application was also observed for the first time. To date, only a limited number of studies on the biological activity of T. serpyllum essential oil have been published. The main components of the EO of T. serpyllum were thymol, 18.8\%; carvacrol, $17.4 \%$; o-cymene, $15.4 \%$; and geraniol $10.7 \%$. The antioxidant activity of EO was high at $82.4 \pm 0.5 \%$, which corresponds to $463.53 \pm 2.60 \mu \mathrm{g}$ Trolox $/ \mathrm{mL}$ sample. T. serpyllum EO had very good antimicrobial effects as well as antibiofilm effects observed on various surfaces and detected by MALDI-TOF MS Biotyper. The MALDI-TOF MS Biotyper was a suitable method for evaluating phases of biofilm development. T. serpyllum EO demonstrated inhibitory activity on microorganisms in a food model in the vapor phase. The present study showed some new findings on the characteristics of T. serpyllum EO which should be a suitable alternative to extend the shelf-life of root vegetables and to the chemical control of Penicillium on bread. 
Author Contributions: Conceptualization, L.G. and M.K.; data curation, L.G., P.B., N.L.V., M.V., J.Š., H.Ď., V.V., and M.K.; methodology, L.G., P.B., N.L.V., M.V., J.Š., H.Ď., V.V., and M.K.; supervision, M.T. and M.K.; writing—original draft, L.G., P.B., M.T., P.Ł.K., and M.K. All authors have carefully revised and approved the final version of the manuscript.

Funding: This work was supported by the grant APVV SK-BY-RD-19-0014 "The formulation of novel compositions and properties study of the polysaccharides based edible films and coatings with antimicrobial and antioxidant plant additives".

Institutional Review Board Statement: Not applicable.

Informed Consent Statement: Not applicable.

Data Availability Statement: Data is contained within the article.

Acknowledgments: This work has been supported by the grants of the VEGA no. 1/0180/20.

Conflicts of Interest: The authors declare no conflict of interest.

\section{References}

1. Jovanović, A.A.; Đorđević, V.B.; Zdunić, G.M.; Pljevljakušić, D.S.; Šavikin, K.P.; Gođevac, D.M.; Bugarski, B.M. Optimization of the extraction process of polyphenols from Thymus serpyllum L. herb using maceration, heat- and ultrasound-assisted techniques. Sep. Purif. Technol. 2017, 179, 369-380. [CrossRef]

2. Jarić, S.; Mitrović, M.; Pavlović, P. Review of Ethnobotanical, Phytochemical, and Pharmacological Study of Thymus serpyllum L. Evid Based Complement Alternat. Med. 2015, 2015, 101978. [CrossRef] [PubMed]

3. Verma, R.S.; Padalia, R.C.; Saikia, D.; Chauhan, A.; Krishna, V.; Sundaresan, V. Chemical composition and antimicrobial activity of the essential oils isolated from the herbage and aqueous distillates of two Thymus species. J. Essent. Oil. Bear. Plants 2014, 19, 936-943. [CrossRef]

4. Ahmad, A.M.; Khokhar, I.; Ahmad, I.; Kashmiri, M.A.; Adnan, A.; Ahmad, M. Study of antimicrobial activity and composition by Gc/ms spectroscopic analysis of the essential oil of Thymus serphyllum. J. Food Saf. 2006, 5, 56-60.

5. Soković, M.D.; Vukojević, J.; Marin, P.D.; Brkić, D.D.; Vajs, V.; Griensven, L.J.L.D. Chemical Composition of Essential Oilsof Thymus and Mentha Speciesand Their Antifungal Activities. Molecules 2009, 14, 238-249. [CrossRef] [PubMed]

6. Čabarkapa, I.; Čolović, R.; Đuragić, O.; Popović, S.; Kokić, B.; Milanov, D.; Pezo, L. Anti-biofilm activities of essential oils rich in carvacrol and thymol against Salmonella Enteritidis. Biofouling 2019, 35, 361-375. [CrossRef] [PubMed]

7. Liu, F.; Jin, P.; Gong, H.; Sun, Z.; Du, L.; Wang, D. Antibacterial and antibiofilm activities of thyme oil against foodborne multiple antibiotics-resistant Enterococcus faecalis. Poult. Sci. J. 2020, 99, 5127-5136. [CrossRef] [PubMed]

8. Hong Wu, H.; Moser, C.; Wang, H.Z.; Høiby, N.; Song, Z.J. Strategies for combating bacterial biofilm infections. Int. J. Oral. Sci. 2014, 7, 1-7. [CrossRef]

9. Verderosa, A.D.; Totsika, M.; Fairfull-Smith, K.E. Bacterial biofilm eradication agents: A current review. Front. Chem. 2019, 7, 824. [CrossRef] [PubMed]

10. Mousavian, D.; Nafchi, A.M.; Nouri, L.; Abedinia, A. Physicomechanical properties, release kinetics, and antimicrobial activity of activated low-density polyethylene and orientated polypropylene films by Thyme essential oil active component. J. Food Meas. Charact. 2021, 15, 883-891. [CrossRef]

11. Jeican, I.I.; Tudoran, B.L.; Florea, A.; Flonta, M.; Trombitas, V.; Apostol, A.; Dumitru, M.; Aluaș, M.; Junie, L.M.; Albu, S. Chronic rhinosinusitis: MALDI-TOF mass spectrometry microbiological diagnosis and electron microscopy analysis; experience of the 2nd otorhinolaryngology clinic of Cluj-Napoca, Romania. J. Clin. Med. 2020, 9, 3973. [CrossRef] [PubMed]

12. Naghdibadi, H.; Abdollahi, M.; Mehrafarin, A.; Ghorbanpour, M.; Tolyat, M.; Qaderi, A.; Yekta, M.G. An Overview on Two Valuable Natural and Bioactive Compounds, Thymol and Carvacrol, in Medicinal Plants. J. Med. Plants 2017, 16, 1-32.

13. Nikolić, M.; Glamočlija, J.; Ferreira, I.C.F.R.; Calhelha, C.R.; Fernandes, Â.; Marković, T.; Marković, D.; Giweli, A.; Soković, M. Chemical composition, antimicrobial, antioxidant and antitumor activity of Thymus serpyllum L., Thymus algeriensis Boiss. and Reut and Thymus vulgaris L. essential oils. Ind. Crop. Prod. 2014, 52, 183-190. [CrossRef]

14. Baj, T.; Biernasiuk, A.; Wróbel, R.; Malm, A. Chemical composition and in vitro activity of Origanum vulgare L., Satureja hortensis L., Thymus serpyllum L. and Thymus vulgaris L. essential oils towards oral isolates of Candida albicans and Candida glabrata. Open Chem. 2020, 18, 108-118. [CrossRef]

15. Kovačević, Z.; Radinović, M.; Čabarkapa, I.; Kladar, N.; Božin, B. Natural agents against bovine mastitis pathogens. J. Antibiot. 2021, 10, 205. [CrossRef] [PubMed]

16. Šojić, B.; Tomović, V.; Kocić-Tanackov, S.; Kovačević, D.B.; Putnik, P.; Mrkonjić, Ž.; Đurović, S.; Jokanović, M.; Ivić, M.; Škaljac, S.; et al. Supercritical extracts of wild thyme (Thymus serpyllum L.) by-product as natural antioxidants in ground pork patties. LWT Food. Sci. Technol. 2020, 130, 109661. [CrossRef]

17. Tazabayeva, K.A.; Sylibaeva, B. Chemical composition of the essential oil and flavonoids of Thymus serpyllum L., growing on territory of the east Kazakhstan. Acta Pol. Pharm. 2018, 7, 1329-1337. [CrossRef] 
18. Pruteanu, A.; Popescu, C.; VLADUT, V.; GAGEANU, G. Biochemical analysis of some vegetal extracts obtained from indigenous spontaneous species of Thymus serpyllum L. Rom. Biotech. Lett. 2018, 23, 14013-14024. [CrossRef]

19. Council of Europe. European Pharmacopoeia, 10th ed.; Council of Europe: Strasbourg, France, 2019.

20. European Medicines Agency Assessment Report on Thymus vulgaris L., Thymus zygis Loefl. ex. L., Aetheroleum. Available online: https:/ / www.ema.europa.eu/en/documents/herbal-report/final-assessment-report-thymus-vulgaris-l-thymus-zygisloefl-ex-1-aetheroleum_en.pdf (accessed on 15 March 2020).

21. Kulisic, T.; Radonic, A.; Milos, M. Antioxidant properties of thyme (Thymus vulgaris L.) and wild thyme (Thymus serpyllum L.) essential oils. Ital. J. Food. Sci. 2005, 17, 315-324. Available online: https:/ / www.researchgate.net/profile/Mladen-Milos/ publication/287954724 (accessed on 20 April 2021).

22. Hussain, A.I.; Anwar, F.; Chatha, S.A.S.; Latif, S.; Sherazi, S.T.H.; Ahmad, A.; Worthington, J.; Sarker, S.D. Chemical composition and bioactivity studies of the essential oils from two Thymus species from the Pakistani flora. LWT Food. Sci. Technol. 2013, 50, 185-192. [CrossRef]

23. Goja, I.; Ulici, A.; Culea, M.; Munteanu, V.; Podea, P. The influence of geographic location and enzyme-assisted extraction on essential oils composition of Thymus serpyllum growing wild in Transylvania. Stud. Univ. Babes Bol. Chem. 2020, 65, 135-147. [CrossRef]

24. Ouedrhiri, W.; Balouiri, M.; Bouhdid, S.; Moja, S.; Chahdi, O.F.; Taleb, M.; Greche, H. Mixture design of Origanum compactum, Origanum majorana and Thymus serpyllum essential oils: Optimization of their antibacterial effect. Ind. Crop. Prod. 2016, 80, 1-9. [CrossRef]

25. Wesołowska, A.; Grzeszczuk, M.; Jadczak, D.; Nawrotek, P.; Struk, M. Comparison of the chemical composition and antimicrobial activity of Thymus serpyllum essential oils. Not. Bot. Horti Agrobo. 2015, 43, 432-438. [CrossRef]

26. Nazzaro, F.; Fratianni, F.; De Martino, L.; Coppola, R.; De Feo, V. Effect of essential oils on pathogenic bacteria. Pharmaceuticals 2013, 6, 1451-1474. [CrossRef] [PubMed]

27. Szabó, M.A.; Varga, G.Z.; Hohmann, J.; Schelz, Z.; Szegedi, E.; Amaral, L.; Molnár, J. Inhibition of Quorum-sensing Signals by Essential Oils. Phytother. Res. 2010, 24, 782-786. [CrossRef] [PubMed]

28. Camele, I.; Elshafie, H.S.; Caputo, L.; De Feo, V. Anti-quorum Sensing and Antimicrobial Effect of Mediterranean Plant Essential Oils Against Phytopathogenic Bacteria. Front. Microbiol. 2019, 10, 2619. [CrossRef] [PubMed]

29. Božik, M.; Cejnar, P.; Šašková, M.; Nový, P.; Maršík, P.; Klouček, P. Stress response of Escherichia coli to essential oil components -Insights on low-molecular-weight proteins from MALDI-TOF. Sci. Rep. 2018, 8, 13042. [CrossRef] [PubMed]

30. Kırmusaoğlu, S. Antimicrobials, Antibiotic, Resistance, Antibiofilm Strategies and Activity Methods, 1st ed.; IntechOpen: London, UK, 2019; pp. 99-102. [CrossRef]

31. Stîngu, C.S.; Rodloff, A.C.; Jentsch, H.; Schaumann, R.; Eschrich, K. Rapid identification of oral anaerobic bacteria cultivated from subgingival biofilm by MALDI-TOF-MS. Oral. Microbiol. Immun. 2008, 23, 372-376. [CrossRef] [PubMed]

32. Gaudreau, A.M.; Labrie, J.; Goetz, C.; Dufour, S.; Jacques, M. Evaluation of MALDI-TOF mass spectrometry for the identification of bacteria growing as biofilms. J. Microbiol. Meth. 2018, 145, 79-81. [CrossRef] [PubMed]

33. Aguiar, P.A.D.F.; Menezes, R.P.; Penatti, M.P.A.; Moreira, T.A.; Pimenta, J.P.; Silva, N.B.S.; Röder, D.V.D.B. Rapid detection of biofilm-producing Candida species via MALDI-TOF mass spectrometry. J. Appl. Microbiol. 2021. [CrossRef] [PubMed]

34. Kačániová, M.; Terentjeva, M.; Galovičová, L.; Ivanišová, E.; Štefániková, J.; Valková, V.; Borotová, P.; Kowalczewski, P.Ł.; Kunová, S.; Felšöciová, S.; et al. Biological activity and antibiofilm molecular profile of Citrus aurantium essential oil and its application in a food model. Molecules 2020, 25, 3956. [CrossRef] [PubMed]

35. Kačániová, M.; Galovičová, L.; Ivanišová, E.; Vukovic, N.L.; Štefániková, J.; Valková, V.; Borotová, P.; Žiarovská, J.; Terentjeva, M.; Felšöciová, S.; et al. Antioxidant, antimicrobial and antibiofilm activity of coriander (Coriandrum sativum L.) essential oil for its application in foods. Foods 2020, 9, 282. [CrossRef] [PubMed]

36. Střelková, T.; Nemes, B.; Kovács, A.; Novotný, D.; Božik, M.; Klouček, P. Inhibition of Fungal Strains Isolated from Cereal Grains via Vapor Phase of Essential Oils. Molecules 2021, 26, 1313. [CrossRef] [PubMed]

37. Feng, W.; Chen, J.; Zheng, X.; Liua, Q. Thyme oil to control Alternaria alternata in vitro and in vivo as fumigant and contact treatments. Food Control 2011, 22, 78-81. [CrossRef]

38. Nedorostova, L.; Kloucek, P.; Kokoska, L.; Stolcova, M.; Pulkrabek, J. Antimicrobial properties of selected essential oils in vapour phase against foodborne bacteria. Food Control 2009, 20, 157-160. [CrossRef]

39. Tyagi, A.K.; Malik, A. Antimicrobial action of essential oil vapours and negative air ions against Pseudomonas fluorescens. Int. J. Food Microbiol. 2010, 143, 205-210. [CrossRef] [PubMed]

40. Goñi, P.; López, P.; Sánchez, C.; Gómez-Lus, R.; Becerril, R.; Nerín, C. Antimicrobial activity in the vapour phase of a combination of cinnamon and clove essential oils. Food Chem. 2009, 116, 982-989. [CrossRef]

41. Fisher, K.; Phillips, C. Potential antimicrobial uses of essential oils in food: Is citrus the answer? Trends Food Sci. Technol. 2008, 19, 156-164. [CrossRef]

42. Inouye, S.; Takizawa, T.; Yamaguchi, H. Antibacterial activity of essential oils and their major constituents against respiratory tract pathogens by gaseous contact. J. Antimicrob. Chemother. 2001, 47, 565-573. [CrossRef] [PubMed]

43. Inouye, S.; Uchida, K.; Abe, S. Vapor activity of 72 essential oils against a Trichophyton mentagrophytes. J. Infect. Chemother. 2006, 12, 210-216. [CrossRef] [PubMed] 
44. Tullio, V.; Nostro, A.; Mandras, N.; Dugo, P.; Banche, G.; Cannatelli, M.A.; Cuffini, A.M.; Alonzo, V.; Carlone, N.A. Antifungal activity of essential oils against filamentous fungi determined by broth microdilution and vapour contact methods. J. Appl. Microbiol. 2007, 102, 1544-1550. [CrossRef]

45. Suhr, K.I.; Nielsen, P.V. Antifungal activity of essential oils evaluated by two different application techniques against rye bread spoilage fungi. J. Appl. Microbiol. 2003, 94, 665-674. [CrossRef] [PubMed]

46. Dao, T.; Bensoussan, M.; Gervais, P.; Dantigny, P. Inactivation of conidia of Penicillium chrysogenum, P. digitatum and P. italicum by ethanol solutions and vapours. Int. J. Food Microbiol. 2008, 122, 68-73. [CrossRef] [PubMed]

47. Edris, A.E.; Farrag, E.S. Antifungal activity of peppermint and sweet basil essential oils and their major aroma constituents on some plant pathogenic fungi from the vapor phase. Nahr. Food 2003, 47, 117-121. [CrossRef] [PubMed]

48. Adams, R.P. Identification of Essential Oil Components By Gas Chromatography/Mass Spectroscopy; Allured Publishing Corporation: Carol Stream, IL, USA, 2007; p. 469.

49. Van Den Dool, H.; Kratz, P.D. A Generalization of the retention index system including linear temperature programmed gas-liquid partition chromatography. J. Chromatogr. A 1963, 11, 463-471. [CrossRef]

50. Bajčan, D.; Tomáš, J.; Uhlířová, G.; Árvay, J.; Trebichalský, P.; Stanovič, R.; Šimanský, V. Antioxidant potential of spinach, peas, and sweetcorn in relation to freezing period. Czech J. Food Sci. 2013, 31, 613-618. [CrossRef]

51. Hassan, A.; Usman, J.; Kaleem, F.; Omair, M.; Khalid, A.; Iqbal, M. Evaluation of different detection methods of biofilm formation in the clinical isolates. Braz. J. Infect. Dis. 2011, 15, 305-311. [CrossRef]

52. Talibi, I.; Askarne, L.; Boubaker, H.; Boudyach, E.H.; Msanda, F.; Saadi, B.; Aoumar, A.A.B. Antifungal activity of some Moroccan plants against Geotrichum candidum, the causal agent of postharvest citrus sour rot. Crop. Prot. 2013, 35, 41-46. [CrossRef]

53. Aman, M.; Rai, V.R. Antifungal activity of fungicides and plant extracts against yellow sigatoka disease causing Mycosphaerella musicola. Curr. Res. Environ. Appl. Mycol. 2015, 5, 277-284. [CrossRef] 